\begin{tabular}{|c|}
\hline $\begin{array}{c}\text { The Social Construction of the Acquis Communautaire: A Cornerstone of the } \\
\text { European Edifice }\end{array}$ \\
\hline Knud Erik Jørgensen \\
\hline $\begin{array}{c}\text { European Integration online Papers (EIoP) Vol. } 3 \text { (1999) } \\
\text { http://eiop.or.at/eiop/texte/1999-005a.htm }\end{array}$ \\
\hline Date of publication in the EIOP: 29.4.1999 \\
\hline $\begin{array}{l}|\underline{\text { Full text }}| \text { Back to homepage }|\underline{\text { PDF }}| \underline{\text { PS }} \mid \\
\mid \underline{\text { This paper's comments page } \mid \text { Send your comment! to this paper } \mid}\end{array}$ \\
\hline Keywords \\
\hline $\begin{array}{l}\text { acquis communautaire, constitution building, enlargement, European identity, europeanization, } \\
\text { governance, law, polity building, power analysis, supranationalism, political science }\end{array}$ \\
\hline Abstract \\
\hline $\begin{array}{l}\text { The acquis communautaire is almost always (self-re)presented as a rock hard principle, as } \\
\text { something applicant countries have to adapt to. Employing a Nietzsche-Foucauldian genealogical } \\
\text { method, the paper explores an important instance of intersubjectivity of meaning among European } \\
\text { integrators, or, in concrete terms, the genealogy of the acquis. The paper explores how the acquis } \\
\text { has become such a powerful non-negotiable condition for accession and traces one origin of the } \\
\text { acquis back to the early 1960s, to the first round of (failed) negotiations on enlargement. The paper } \\
\text { argues that currently there are at least two meanings of the acquis: (i) a political principle and, (ii) a } \\
\text { legal principle, constituting a crucial aspect of constitutionalization in the European Union. Finally, } \\
\text { the paper concludes that despite various direct political attacks, and despite the worries of several } \\
\text { scholars, the acquis seems not at all to be an endangered principle. }\end{array}$ \\
\hline Kurzfassung \\
\hline $\begin{array}{l}\text { Der Acquis Communautaire wird fast immer als ein gesichertes und festes Grundprinzip dargestellt, } \\
\text { als etwas, an das sich die beitrittssuchenden Staaten anpassen müssen. Das Papier untersucht mittels } \\
\text { einer auf Nietzsche und Foucault zurückgehenden geneaologischen Methode ein wichtiges Beispiel } \\
\text { für Bedeutungs-Intersubjektivität unter den europäischen Integrationisten oder, konkreter, die } \\
\text { Genealogie des Acquis. Das Papier erörtert, wie der Acquis eine mächtige, nicht-verhandelbare } \\
\text { Aufnahmebedingung wurde und verfolgt einen Ursprung des Acquis bis in die frühen 1960er Jahre } \\
\text { zurück, nämlich zur ersten Runde der (gescheiterten) Erweiterungsverhandlungen. Der Beitrag } \\
\text { argumentiert, daß es derzeit zumindest zwei Bedeutungen von Acquis gibt: (i) als ein politisches } \\
\text { Prinzip und (ii) als ein rechtliches Prinzip, welches einen entscheidenden Aspekt der } \\
\text { Konstitutionalisierung der Europäischen Union darstellt. Abschließend wird festgestellt, daß der } \\
\text { Acquis trotz vielfacher direkter politischer Angriffe und trotz der Bedenken einiger Wissenschafter } \\
\text { keineswegs ein gefährdetes Prinzip ist. }\end{array}$ \\
\hline \begin{tabular}{|c|c|} 
The author \\
\end{tabular} \\
\hline $\begin{array}{l}\text { Knud Erik Jørgensen is an associate professor in the Department of Political Science at the } \\
\text { University of Aarhus; email: kej@ps.au.dk }\end{array}$ \\
\hline
\end{tabular}




\section{The Social Construction of the Acquis Communautaire: A Cornerstone of the European Edifice( $(*)$}

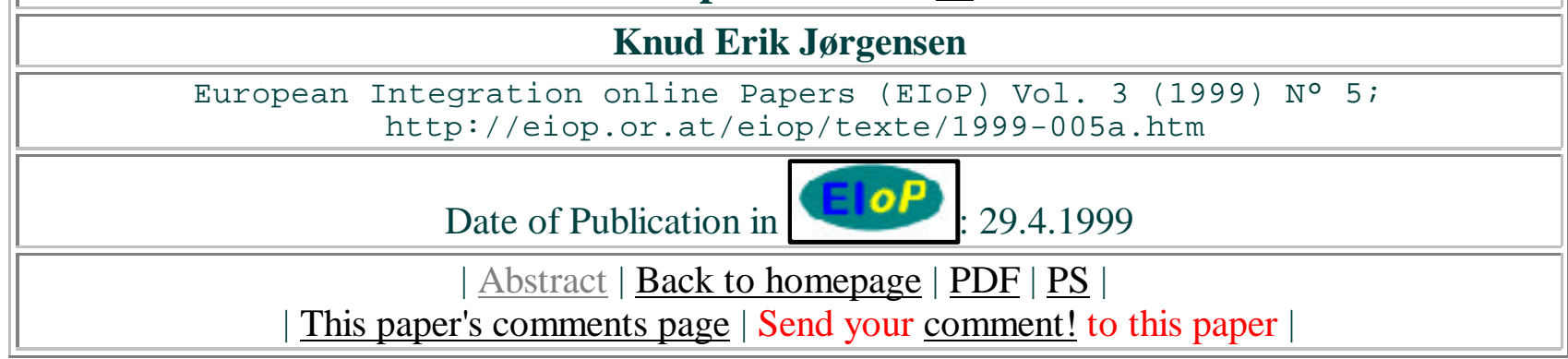

\section{Contents:}

- I. Introduction

- $\underline{\text { II. The genealogical method }}$

- III. Origins

- IV. One Acquis, Many Acquis?

- $\mathrm{V}$. Is the acquis an endangered principle?

- VI. Conclusion

- References

\section{Introduction}

Every single enlargement of the European Union (EU) has prompted debates on issues such as applicants' qualifications, the possible need for EU self-reform, impact on policies like agricultural and regional policy, the balance between widening and deepening - issues which have all been described in a rich literature on EU enlargement. However, it is also worth noticing that every single enlargement has been accompanied by a fairly brief but distinct and seemingly powerful emergence of the so-called acquis communautaire. Whereas the acquis seems to live a dull and uninteresting life between periods of enlargements, it also seems to be one of those immensely important concepts that always finds its way into the headlines of newspapers, magazines, journals and news bulletins when enlargement is on the agenda. It is thus significant that The Economist finds it relevant to inform its readers about what the adoption of the rules of the acquis involves for Eastern Europe( 1$)$ and that the French Ministry of Foreign Affairs, the Quay d'Orsay, with satisfaction notes that "The candidate countries accepted not only the provisions of the European treaties but also the Community rules (the 300 'regulations' or 'directives' making up the 'acquis communautaire') without any permanent derogations".(2) But are these few examples just exceptions to some rule? They are not.

A thorough search in a broad range of news bulletins reveals a veritable bombardment of comments in which the acquis plays a more or less prominent role.()ㅡ While the bombardment as such may surprise, I think it is even more surprising that most comments actually contribute to a clear and consistent pattern. A small sample of quotations from the news bulletins clarifies the pattern I have in mind.

The European Commission will invite candidate countries "to prepare a National Programme for theAdoption of the Acquis" (European Commission Press Release, 11 February 1998). BBC reports that "work has still to be done on bringing Czech law into harmony with the acquis communautaire" 
(BBC Monitoring Service, 9 October 1997). Agence Europe informs one day that Cyprus "already respects almost all the acquis communautaire" (8 October 1997), the next day about the "pre-accession process and the progressive adoption of the acquis communautaire" (9 October 1997) and a third day about the EU to "force the Swiss government to make a clear and unambiguous commitment to adopt the acquis communautaire for the weight and dimensions of lorries" (4 October 1996). At another occasion someone asserts that "Turkey has already proven its capacity to adapt to the 'acquis communautaire'" (European Commission Press Releases, 2 October 1997). Spicer's Centre for Europe informs that "candidate countries need to bring their environmental law in line with the acquis communautaire" (11 September 1997) and Agence Europe adds that "their environmental legislation is far from homogeneous, and the progress still required to absorb the 'acquis communautaire' will require enormous investments, estimated at ecu 120-130 billion a year" (12 September 1997). Even decisions on radio frequencies have to be compatible with the acquis. In a press release, the European Commission points out that "decisions on frequencies in the context of WRCs should comply with the acquis communautaire in terms of mobile communications and general telecommunications objectives" (18 June 1997). In general, Agence Europe finds that "the taking on board the acquis communautaire presents difficulties in many countries (10 July 1997), and, I might add, that is no understatement.(4)

My small sample of quotations makes clear that a consistent pattern emerges, namely that they present the acquis as an "independent variable", as something others should "respect", "adopt", "adapt to", "comply with", "take on board", or bring law "into harmony with".(ㅌ) All these terms suggest that we are dealing with a very powerful phenomenon. All the same, we now leave the world of news bulletins and enter the world of academic commentary.

However, the message, though presented differently, is strikingly similar. Joseph Weiler describes the acquis in his usual vivid language: "The holiest cow of all has been the preservation of the acquis communautaire and, within the acquis, the Holy of Holiest is the constitutional framework of the Community" (1997: 98). Philippe Schmitter explains in a similar language that,

"The acquis communautaire is one of the most sacred of the EC, now EU, concepts. It refers to the sum total of obligations that have accumulated since the founding of the ECSC and are embedded in innumerable treaties and protocols. So far any state which applies to the EC/EU is expected to accept as a matter of principle the responsibility for fulfilling all these obligations, although in the actual negotiations for entry it is possible to delay the application of some of them. It is expressly designed to prevent any prospective member from 'shopping around' for its own mix of obligations" (1996:162).

In Wallace and Wallace's excellent textbook Policy-Making in the European Union, Helen Wallace describes how,

"the acquis was shorthand for the accumulated obligations and commitments agreed under the treaties and legislation of the EC over the years. By definition it was conservative, encouraging Commission officials to limit their policy proposals to established approaches to policy, even when they did not bear fruit. The history of industrial policy and of harmonization affecting non-tariff barriers in the 1970s both illustrate this" (1996:52).

Note that Wallace in the quotation hints at two different dimensions. One is general and concerns 'obligations and commitments...over the years', the other is policy-specific. Various Euro-speak 
dictionaries characterize the acquis in largely similar terms. One "official" glossary informs that,

\begin{abstract}
"The acquis communautaire or Community patrimony is the body of common rights and obligations which bind all the Member States together within the European Union. It is founded principally on the Treaty of Rome and the instruments that supplement it (The Single European Act, the Treaty on European Union etc.), plus the wide range of secondary legislation enacted under them. The acquis communautaire relates mainly to the single market and the four freedoms inherent in it (freedom of movement for goods, persons, capital and services), the common policies which underpin it (agriculture, trade, competition, transport and others) and measures to support the least-favoured regions and categories of the population. The Union has committed itself to maintaining the acquis communautaire in its entirety and developing it further. Exemptions and derogations from the legal framework constituted by the acquis communautaire are granted only in exceptional circumstances and are limited in scope".(ㅁ)
\end{abstract}

Thus, my first cuts into the meaning of the acquis confirm the popular image of it: a very prominent principle; one of the cornerstones of European integration; one of the most fundamental doctrines; a hard core, rock-like condition that all new members of the European Union have to accept; accession negotiations are always presented as a 'take-it-or-leave-it' game; the acquis expresses thus the essence of European multi-level governance, and is one of the key features distinguishing Member States from non-members (though several European non-members have taken on board the acquis or is in the process of doing so, blurring in effect the boundaries between the European Union and the world outside).

My initial description of the acquis leads to several pressing questions and to several possible avenues of inquiry. Obvious questions to raise include the following: if the acquis is this non-negotiable, rock-hard principle, how has it come into being? Who has empowered the acquis? Have the features described above always characterized the acquis? Does a closer examination of the acquis lead to other meanings of the acquis different from the one that appears to be the best known? Which avenue of inquiry looks promising for the task? Among the possible avenues of inquiry one could examine the effects of the acquis, analyze the functions of the acquis in European society, or explain whether it changes state behaviour or not. Though such issues are interesting and relevant for policy issues, my aim is nevertheless something altogether different. The paper's main purpose is to describe the meaning of the acquis and how that meaning came into being. Neither more and nor less. It is thus a paper that employs an interpretive theory.

Interpretative theories come in many versions. Among these, the genealogical method seems to be an excellent choice for the aim of my analysis.(ㄱ) In the next section I describe my choice of method, arguing that a pragmatic, instrumental reading of Nietzsche and Foucault makes their method applicable for empirical research. In the following sections I explore the genesis and development of the acquis. First, I trace its origin back to the 1960s arguing that the principle was introduced even before the term acquis communautaire was coined, i.e., the acquis has been a feature characterizing European integration since its inauguration. While I do not deny the adequacy of understandings described above, my findings do nevertheless suggest a significantly different story. In fact, I argue that the acquis is far from being unchangeable and rock-hard. Rather, it is almost like a living organism. It is constantly being reproduced as an important principle, and many different actors are active in this construction-and-reproduction process. Second, I describe how the acquis has several layers of meaning and argue that it is rather misleading to talk about just the acquis, as if it is a one-of-a-kind phenomenon. Third, I introduce a dilemma between continuity and change and argue 
that on the one hand, the acquis is evolutionary by its very nature - and therefore changeable. Over time social actors have significantly expanded the scope of the acquis, among other things, by means of incorporating ever more policy areas. On the other hand we also have a continuity dimension. i.e., the principle that new members have to accept the acquis as it is, and that the acquis should not be "rolled back". Fourth, I discuss whether the acquis is an endangered principle in the contemporary European Union. I identify five possible threats ("hijacking", subsidiarity, the intergovernmental conference (IGC) 1996-97, the 5th enlargement of the EU, and the UK). I conclude that the rumours about the fall of the acquis is greatly exaggerated.

\section{The genealogical method}

Friedrich Nietzsche and Michel Foucault are the "Godfathers" of the genealogical method. Nietzsche introduced the method in On the Genealogy of Morals (1887/1969) and Foucault summarized his interpretation in the article Nietzsche, Genealogy, History (1971/1984). He has applied the method in, among other works, Discipline and Punish: The Birth of the Prison (1975/1995). It may be surprising here and there that both authors have had a certain impact on contemporary political science and that their production has relevance for current research on European multi-level governance.

In my view, Morrow has a point when he argues that "Part of [Foucault's] immense interdisciplinary impact stems from the way he can mean different things to different researchers" (1994: 135). My reading of Nietzsche and Foucault is predominantly pragmatic, meaning for instance that I do not see a big difference between terms like "individual", "actor", and "subject". Similarly, though both Nietzsche and Foucault did not particularly like structuralism I do include the term "structure" in my genealogical conceptual "raster". Furthermore, it seems to me that they are not unique on al accounts. Indeed they share some of their insights with others. In other words, then, I read them for the simple reason that I think their method can help me better to understand the puzzle described in the first section of this paper. My pragmatic reading is inspired by Richard Price (1995) and Bent Flyvbjerg (1998). Just like them I want to use the genealogical method for empirical research. Hence, my interest in the method is also close to Dreyfus and Rabinow's, i.e. a reading leading towards a method for studying human beings.(ㅇ) Furthermore, my pragmatic reading allows me to focus on how a number of humans create certain rules and principles with an apparently crucial relevance for the construction of Europe. What I do is simply to focus on a term that seems to be a promising starting point for a very important story about European integration. Finally, I am not in thelongue durée business, and unlike Foucault, I do not study prisons over centuries or sexuality over millennia. Rather, my modest aim is to describe the genesis of a principle and trace its development over a span of time for about 40 years.

My reading is not only pragmatic it is also instrumental. I find that even a superficial knowledge of Nietzsche and Foucault makes it pointless to view their method as a rigid social science method. Rather, it is a cluster of guidelines for historical analysis, and in this sense the genealogical method may, with some justification, be called an anti-method - just as, according to Morrow (1994:135), Foucault's sociology may be called antisociology. The genealogical method is thus more research 'strategy' than 'tactics'. An operationalization of the 'strategy' requires the creation of a number of key concepts which are all important for an instrumental application of the method.

Origins. The method has, cf. its name, something to do with the origin of things, i.e., with issues like where does this or that phenomenon come from? How has it been created, developed or cultivated? In short, how can one describe its genealogy? Yet, not any search for origin goes. We should avoid 
thinking according to which rational function equals origin. This brings me to two key Nietzsche quotations,

"It is my purpose here to bring to light, not what this ideal has done, but simply what it means; what it indicates; what lies hidden behind it, beneath it, in it; of what it is the provisional, indistinct expression, overlaid with question marks and misunderstandings... What is the meaning of the power of this ideal?... Why has it been allowed to flourish to this extent?"

\begin{abstract}
"The cause of the origin of a thing and its eventual utility, its actual employment and place in a system of purposes, lie worlds apart; whatever exists, having somehow come into being, is again and again reinterpreted to new ends ... and the entire history of a "thing", an organ, a custom can in this way be a continuous sign-chain of ever new interpretations and adaptations whose causes do not even have to be related to one another but, on the contrary, in some cases succeed and alternate with one another in a purely chance fashion" (quoted from Price, 1995: 85).
\end{abstract}

Price made me aware of these quotations, indeed it was when I read Price's article that I realized I had found an adequate approach to use for my investigation of the acquis' genealogy. Nietzsche makes us aware of the crucial distinction between 'have done' and 'means'. What the acquis has 'done' is an issue Goebel (1995) deals exemplary with though he is by far not the only one to do so. Concerning the 'what it means?' I read (in the Nietzsche quotations) 'acquis' instead of 'ideal' and 'thing', and I think the relevance of a Nietzschean genealogy becomes very clear though probably - nota bene - more in a hypothetical than a conclusive mode.

Discourse and Marginalization. According to Price's interpretation of Nietzsche and Foucault, discourses construct categories, meaning that sets of practice and understanding look unthinkable or illegitimate, something which leads to conceptual possibilities defining what is normal and natural, and what is unthinkable and blame-worthy. Norms of this type do not only limit behaviour, but are also productive by constituting identities, meanings and understandings of that which counts as legitimate reality. It is widely accepted that genealogy cultivates the ability to take into account the marginalized and peripheral aspects that tend to be neglected by history or history-tellers. I see two possible purposes for such an endeavour. Some analysts have the intention to tip the balance between privileged and marginalized, i.e. by means of analysis to give "voice" to the silenced. The second purpose is to focus on marginalization in order to better understand the ongoing balance-of-power game between marginalized and privileged, i.e. to understand better the actual outcome by means of examining potential but not materialized outcomes. Such a reading, the one chosen for this paper, is fairly similar to the use of counterfactuals in historical analysis (Fearon, 1991). Because I want to focus, among other things, on certain aspects concerning the acquis that have been neglected, marginalized or simply forgotten, genealogy seems to be an ideal method for analyzing various historically contested meanings of the acquis. Or put differently, to focus on discursive strategies that have been employed in order to load the acquis with its status as something beyond debate, something untouchable.

Power. Historically, the concept of power has not played a prominent role in studies of European integration. The first major integration theory constructs, functionalism and neofunctionalism, both avoid reflections on power. In this context, it is significant that Ernest Haas (1953) published a critique of the balance of power concept before he published his classics on regional integration.(9) He found that the concept was devoid of meaning and therefore not very useful for academic 
inquiries. Other theoretically informed studies of European integration did include reflections on the role of power, but power was then conceived in terms of material power or in terms of traditional balance of power logics, and the aim of research was often to explain the limits of integration. To my knowledge, discursive power has seldom played a prominent role in studies of European integration. This, of course, is where Foucault comes in, primarily because he considers discourses to be a very important form of power, a form he calls disciplining power. Price (1995) points out how the genealogical method introduces a different dimension of power in the study of norms. We can analyze conflicts concerning interpretive truths, that is, the execution of power which is localized in other spheres than those typically granted attention in research on European integration.

Contingency. Genealogy is generally very sensitive to historical contingency, i.e., to what I call floating structures in historical space. According to Price, scholars should be aware of "the error of ignoring 'the specific historical and genealogical tangles that produce the contingent structures we mistakenly consider given, solid, and extending without change into the future as well as into the past"' (1995: 85).(10) However, this insight is not exclusive to genealogists. It seems to me that Charles Tilly thinks along similar lines, "As a practical matter, however, retrospective investigation is unlikely to yield valid prospective conclusions, and vice versa" (1975:15). Other concepts which are relevant to consider in this context include "reification" and Berger and Luckmann's (1966) notion of "institutionalisation". As I described in the introductory section, we all tend to believe that the acquis has always been what it is today, and that the acquis also in the future will be among key European integration principles. Assuming that the acquis is a contingent structure, it seems worthwhile to explore the "specific historical and genealogical tangles" by which the acquis has been "loaded" with its previous and current meanings.

Structure. Foucault has often declared that "I have never been a structuralist" (quoted in Mahon, 1992:180). Mahon adds that Foucault does not share a view after which structures are "invariant universals" (1992:9) or "atemporal" (1992:29). How do I then dare to include the term "structure" in my list of key concepts? Simply because an awareness of structures in the social world does not make one a structuralist, and because other structures than "atemporal", "invariant universal" structures are imaginable. In my view, the acquis is a very good example of what Wendt (1995) depicts as "social structure" and what Kratochwil (1989) terms "institutional fact". The acquis is a very concrete social structure which automatically confronts new members of the EU and something which they have to accept and adapt to. Among other things, they have to change a considerable number of national laws in order to become Euro-compatible. They have to accept key principles in the European legal order such as direct effect and supremacy of European law. By extension of the argument that contemporary European states are most adequately characterized as post-modern states (Caporaso, 1996; Cooper, 1996; Sørensen, 1997) I argue that precisely the acceptance and adaptation to the acquis is a very important part of what transforms modern European nation-states into post-modern EU Member States, or, put differently, the acquis is nothing less than among the defining features of post-modern European statehood. It seems to me that genealogy is a very helpful method to use in an analysis about how the social (acquis)structure has been historically constructed and how it is being reproduced by social actors.

Actors. Any analysis that focuses too much on structural features runs the risk of treating actors in a deterministic or mechanical way; actors become oversocialized and changes between structures of discourse become difficult to understand; co-constitution of agency and structure, so prominent in structuration theory, becomes difficult to grasp. I try to avoid such problems by identifying potential key actors, and furthermore by installing an analytical vigilance towards processes of co-constitution. Who has contributed to the constitution and reproduction of the acquis as a principle that seems 
unchangeable, to exist beyond political and judicial debate, a modern taboo? Intuitively, the following actors seem to play particularly prominent roles in the construction or reproduction of the acquis. The European Court of Justice (ECJ) and national courts by constructing or reproducing authoritative meanings of the concept; The European Commission, particularly but not only concerning the accession acquis; Member States, by not attacking or reducing the importance of the acquis in any fundamental way - and by explicitly supporting traditional understandings of the acquis; The Council Secretariat - by always mentioning the acquis in drafts for European Council declarations; epistemic communities - by constructing or reproducing the discourse; the European Parliament by adding to others' efforts to constitutionalize the Treaties.

Data. According to Foucault, "Genealogy will attempt to research beyond the bounds of treaties, battles and the like, unities homogenized by a historical will to order. Rather, genealogy privileges and cultivates details and accidents that accompany every beginning and while it does not oppose itself to history, it does oppose itself to the search for origin" (Foucault, 1971/1984). Because orderly people in general and academics in particular have a strong "will to order" it is unnecessary to point out that Foucault's prescription for them constitute something close to heresy. It has clearly also something to do with types of data. Traditional history is out just as presentation of historical development as magnificent lines of progress is precluded. Flyvbjerg (1991) adds that genealogists often deal with "a vast accumulation of source material". I can only confirm his observation. It is pretty scary that my "source material" potentially includes all European Council and Council declarations; the European Commission's opinions on applicants, as well as other documents related to the Commission's dealings with applicants; the ECJ's rulings; epistemic (lawyer) communities and their interpretations of European law and constitutionalism; Member States' subjective and intersubjective understandings of the acquis; finally, broader commentary in various media.

Grey. Genealogy is often being described as 'grey'. Genealogy may still be grey but in my case I think it is grey in a slightly different nuance, the reason being that I do not have to dig through piles of dusty documents in order to describe the genealogy of the acquis. Computerization makes a difference. The following is not a comprehensive account for my search strategy but is merely an illustration of how computerization makes a difference. First, searching the European Commission's website (http://europa.eu.int) for the search words acquis and communautaire informs you about at least two things: first, that 902.233 documents have been searched, and two, that the words acquis or communautaire are mentioned in several thousands of these documents. I am perfectly aware that such a search has its informative limits: (i) it only constitute a scratch in the surface. Yet, I think it allows me to conclude that the pile of documents with "hits" is more interesting to analyze than the other pile; (ii) documents may exist in which the term "acquis communautaire" has been translated into other official languages of the European Union;(11) (iii) there may be documents in which the meaning of the acquis occurs without the term. Second, the EU's ECLAS and SCAD databases scan some 1500 journals, and, upon request, inform you about some 100 journal articles which has acquis communautaire in their title or as descriptor. That has been a very helpful shortcut to my reading about the acquis. Third, the Dialog databases, including particularly Reuters' Textline, can provide a very helpful scanning of the pink news bulletin Agence Europe, indispensable for anyone with a serious interest in European Union affairs. Despite all the problems inherent in such an approach it seems to me that genealogy (in my case) is grey in a slightly different nuance. However, having in mind my reading of document after document, I can confirm that genealogy continues to be meticulous and patiently documentary.

Finalities. In a book that is essential for interpretations of Foucault, Dreyfus and Rabinow point out that, 
"for the genealogist there are no solid essences, no underlying laws, no metaphysical finalities. Genealogy seeks out discontinuities where others found continuous development. It finds recurrences and play where others found progress and seriousness. It records the past of mankind to unmask the solemn hymn of progress. Genealogy avoids the search after depth. Instead it seeks the surfaces of events, small details, minor shifts, and subtle contours. It shuns the profundity of the great thinkers our tradition has produced and revered" (1983: 106).

While Dreyfus and Rabinow here demonstrate the heuristic value of overstatement and simplification they, nevertheless, also neatly summarize the key features of genealogy. Steve Smith helpfully adds (with a Foucault quotation) that, the genealogist finds "not a timeless and secret essence, but the secret that [things] have no essence or that their essence was fabricated in a piecemeal fashion from alien forms" (1995: 4). Does the acquis not have a timeless 'essence'? Was the acquis "fabricated" in a piecemeal fashion?

In summary, the genealogical method seems particularly well-suited for my investigation of the acquis. It cultivates awareness concerning features like origin, contingency, agency and structure, discursive power, finalities, and grey documentation. Thus equipped with a specified conceptual raster and a certain unconventional understanding of historical development, I proceed to analyze the genealogy of the acquis.

\section{Origins}

In line with my choice of method I am not tracing the origin of the acquis in order to reveal some deep truth about the acquis. I do not expect to find the "essence" or to discover any hidden secrets about the acquis. Rather, my point of departure is the commonsensical fact that the acquis has not always been around. At some point the term was coined, and was inserted into the discourse on European integration. Indeed, precisely because the acquis has an origin it is possible to describe its genealogy. Unfortunately, it has not been possible to trace down the moment when the term acquis communautaire was coined for the first time. Yet, it is easy to see that the acquis is one of many French terms in Euro-speak.

The former ECJ-judge, Pierre Pescatore, emphasizes two important characteristics, "L'acquis communautaire dont on peut parler en l'annee 1981 est le resultat d'une lante accumulation, d'un processus relativement long de maturation" (1981: 649). First, one should note the expression "the acquis of which one can speak in 1981". By this Pescatore highlights historical contingency. It follows logically that the acquis people talked about in 1971 or 1997 may be of a wholly or partly different nature. Second, he emphasizes that the acquis is the result of a long period of accumulation, of a relative long process of maturation. But not only that. In the same article, Pescatore also identifies a beginning, an origin of the acquis: "Tout prend son origine dans quatre arrêts: Commission $C$. Luxembourg et Belgique, affaire dite pain d'épice (1962), Van Gend et Loos (1963), Costa C. ENEL (1964), Consten et Grundig (1966). Voilà donc une base solide posée dès que surgissent les premiers problèmes contentieux plus fondamentaux dans la vie communautaire" (1981: 649). Does this identification of an origin contradict the key principle of genealogy, that is, not to search for origins? In my view, it does not. I do not search some essence of the acquis in its origin but merely points out that certain sources constitute the acquis in some form. In Pescatore's convincing analysis, four rulings by the ECJ in the early 1960s constitute one of the origins of the acquis. 
However, other analysts arrive at different conclusions. According to Goebel (1995), the origin of the acquis should be found in the process in the late 1960s which led to the first enlargement of the EC. Gialdino (1995:1090-1) goes further back and also includes the failed enlargement negotiations in the early 1960s. Compared with Goebel' analysis, I find Gialdino's study the more convincing. When the issue of enlargement entered the European agenda for the first time, the EC Member States had to define an approach for enlargement. The need for defining criteria was particularly urgent as the UK had a clear preference for a variable geometry approach to integration. Preston (1995) presents a similar interpretation: "De Gaulle's rejection of the UK's application in 1963 was in effect a judgement that the UK was unwilling or incapable of adapting to the acquis" (1995: 452). When the issue of enlargement reentered the agenda in 1967 and in 1969, 'the Six' therefore had a clear policy. Note also that preston see an acquis at a time (1963) when it, according to Pescatore, hardly was invented.

Though a process, Goebel suggests that the construction of the acquis can be boiled down to one opinion expressed in three statements during the Autumn of 1969. The European Commission produced its Opinions on each of the four applicants (the UK, Ireland, Norway and Denmark). According to the Commission it was a key principle that the achievements of European integration were beyond negotiation. The Hague Summit endorsed the Commission's view, which was also emphasized when Council President, Harmel, opened negotiations. Goebel concludes: "Thus, the principle of the acquis communautaire became an authoritatively stated condition for the first enlargement and subsequently for any future enlargement" (1995: 1142). He summarizes the content of the acquis in a very helpful fashion:

"1) the Treaties, 2) the institutional structure, 3) the legislation and other acts of the Community, 4) international agreements entered into by the Community, 5) legislation and other acts adopted during the negotiations, 6) the somewhat vague concept of the 'political objective' of the Treaties" (1995: 1143).

However, this is not all. Goebel points out that a seventh element of the acquis was introduced "quite without fanfare" (1995: 1143). The Commission simply added an element just before the Act of Accession was signed by declaring that fundamental doctrines of European law (direct effect, supremacy, and uniform interpretation) was part of the Community's legal order: "Accession implies recognition of the binding nature of these rules, observance of which is indispensable to guarantee the effectiveness and unity of Community law" (quoted from Goebel, 1995: 1144). Though the element is not mentioned in the Act of Accession of 1972, Goebel concludes that "it may be regarded as an authentic further aspect of the acquis communautaire principle" (1995:1144) - and he adds that this inclusion of legal doctrines is "no small matter".(12) This is a very adequate conclusion but at the time it was more disputed than Goebel's analysis suggests. A Danish constitutional law adviser, Max Sørensen, who then served the Danish government, declared that the doctrine of supremacy "was just a theoretical possibility, and that judicial practice pointed in a different direction". Despite such contestation, the first enlargement constituted the acquis in a new and more powerful fashion. In my view, we here see an example of the 'detail' and 'accident' by which the acquis is constituted.

However, it is important to note that the principle continued to be dynamic. Later enlargements added further elements to the acquis.

The first Mediterranean enlargement (Greece, Portugal and Spain) added democratic principles and respect for human rights to the acquis. $(\underline{13})$ While the immediate reason for the expansion of the acquis principle probably is linked to the three applicants' recent past state identity (authoritarian regimes), the expansion nevertheless elevates these concerns to the level of key aspects of a key principle. The method to consolidate and expand the scope of the acquis was similar to the method 
applied during the first enlargement, that is, a mixture of Commission opinions and European Council statements (for a detailed analysis, see Goebel, 1995: 1145-1150; on Spanish adaptation to Community Law, see Arpio Santacruz, 1991). The 1995 enlargement (Austria, Finland and Sweden) was a natural occasion to confirm the traditional "take-it-or-leave-it" approach to new applicants which the Commission and the European Council also did (for instance, European Commission opinion on Austria, 1991). The 1995 enlargement took place after the Treaty on European Union went into force, meaning that applicants had to accept all the features of the new treaty, including the EMU project, the Common Foreign and Security Policy (CFSP) and the so-called Third Pillar on Home and Justice Affairs (on the impact of the acquis on Austrian law, see Egger 1996a, 1996b). Particularly the CFSP element - with its provisions on defence policy - appeared to be difficult for the three traditionally neutral and non-aligned applicants to accept. What the applicants did was to declare that they accepted the CFSP; furthermore, they downplayed neutrality as an important dimension of their foreign policy; and finally, they underlined their non-aligned status (meaning 'no thanks' to the Western European Union's (WEU) invitation to join). The TEU also prompted the Commission to add a novel aspect to the acquis, namely "the principle of an open market economy with free competition" (quoted from Goebel, 1995: 1155). This novel aspect was most likely introduced because of the shadow of the future, meaning the easily predictable future enlargement with Central and East European states.

Compared with Pescatore's analysis, Goebel's is quite different, and for good reasons. While Pescatore explicitly analyses the legal aspects of the acquis, Goebel includes both legal and political aspects. He describes in an excellent and very detailed fashion how various legal and political aspects became a "package" during the first enlargement process. Goebel then describes how the acquis later on was equipped with legal and constitutional dimensions. Whereas the ECJ in earlier phases focused its work on the introduction of new legal doctrines and the production of a substantial portfolio of case law rulings, the ECJ directly supported the acquis principle as it was constituted by the Commission and the European Council. By means of a number of case rulings, the ECJ created a hierarchy between the acquis and the Acts of Accessions - to the advantage of the acquis. It was by and large during the same time that the ECJ began to use the term 'constitutional charter' for the treaties, an evolution which reached its zenith with the inclusion of the termacquis communautaire in the TEU (for a detailed analysis, see Goebel, 1995: 1150-1154) - and later in the Amsterdam Treaty. What had hitherto just been a package of aspects of political and legal principles somehow merged into the more tightly woven fabric of a constitutional principle.

In summary, the origin of the acquis is traceable to the early 1960s, though it was then quite different when compared with the status of the principle today. The term acquis seems very appropriate to use for this development as a number of "embryo" aspects constituted the origin, and element after element have been added ever since. This indicates that there is not just one but several "origins", one for each time various actors have expanded the "original" acquis, given it a "twist" in some direction, or interpreted it in a "slightly" different manner. The major players have been the Commission, the ECJ, and the Member States, partly independently, partly through the Council and the European Council. The search for the acquis' origin shows that there is no 'essence' to be found at the origin, indeed there is not only one but several origins, meaning in turn that the acquis has been 'fabricated in a piecemeal fashion'. Furthermore, the search for origin has shown that the acquis seems to have both political, legal and constitutional dimensions. The following section will go into more detail on these dimensions.

\section{One Acquis, Many Acquis?}


Very misleading in their simplicity, most references are to the acquis as if it is just the one and only one. Yet if there is more than one, how many are there? Goebel (1995) provides part of the answer. Though he does not make a major point out of it, his analysis, nevertheless, points to the existence of at least two different meanings of the acquis. One meaning is the acquis as a 'political' principle, originally constructed when The Six had to develop a policy towards enlargement, i.e. an acquis that has been reproduced and expanded ever since. This 'political' acquis includes two dimensions: the political principle implying that new members have to accept the acquis in full and unconditionally and, second, the acquis as the accumulated achievements over time. The other meaning is the acquis as a 'legal' principle, of which the major legal doctrines of European law were the original building blocs, and the constitutionalization of the acquis in the TEU and the Amsterdam Treaty the apparent highest plateau. The two meanings entered the genealogy at different times, and over time they have related to each other differently. Sometimes they existed in parallel but separated at other times they virtually merged. Obviously, this bifurcation of the meaning of acquis undermines the unambiguous and misleading notion of the acquis as simply the acquis. But is it only bifurcation that complicates the simple picture of the acquis?

According to Gialdino the answer is no. He describes (1995:1090-1103) how we, before the Maastricht Treaty, had at least four categories of acquis: accession, Lomé, institutional and the European Economic Area (EEA) acquis. However, he also includes a very interesting discussion of the so-called fundamental or constitutional acquis. Finally, it seems to me that besides the acquis described by Gialdino, it is getting increasingly widespread to use the term acquis in connection with specific policies. The different meanings of acquis is presented in figure 1 and described in further detail below.

\section{Figure 1}

Accession acquis. The acquis I described in the introductory section of this paper is largely what is understood by the accession acquis. The distinction between a 'political' and a 'judicial' acquis described above are two aspects within the same category. Gialdino introduces a third aspect: the normative acquis, meaning provisions that are "beyond the Community law strictu senso" (1995: 1092) including specific treaties associated with the European project, and the so-called acquis politique (i.e., provisions regulating political cooperation). He concludes that it is possible, after the Maastricht TEU went into force, to speak about a narrow Community acquis and a broader Union acquis.

Institutional acquis. According to Gialdino it "signifies a means to safeguard the uniqueness and originality of the model created by the Treaties of Paris and Rome, and to avoid the risk of it being fundamentally modified as a result of intergovernmental positions liable to lead to the re-nationalization of the Community institutions, even before that of Community politics" (1995:1100).

EEA acquis. The EEA-regime was signed in 1992 by the European Community and the, at the time, European Free Trade Area (EFTA) countries. It was introduced as a temporary substitute for membership of the Community. The regime is a very comprehensive set of rules. According to Gialdino it "includes more than 1400 acts published in the O.J. as at 31 July 1991" (1995: 1102; see also Sussman et al., 1991). After the accession of Austria, Sweden and Finland, the EEA regime comprises Norway and Iceland, meaning that these countries are close to being full EU members in economic but not in political terms. There is a very high degree of overlap between the EEA and the SEM acquis. 
Policies acquis. The issues scholars analyze in connection with policy acquis range from the acquis' possible impact on Swiss banking secrecy (Peters, 1991); educational policy (Lenaerts, 1994); food policy (Fraselle, 1994); agriculture (Blumann, Denis and Olive, 1991); economic and monetary policy (Daviddi and Ilzkovitz, 1997); competition policy (Rouam, 1992); Internal Market (Raelison, 1994); foreign policy - the so-called acquis politique (Gialdino, 1995: 1093-6; Jørgensen, 1997); the acquis on borders (Wiener, forthcoming); the environmental acquis(14); and the acquis on citizen rights (Garrone, 1993; Wiener, 1997). Apart from the fact that they all focus on specific policies their focus is quite different. Some authors discuss the legal competence to develop policies within a specific field, others discuss the impact of the acquis on a specific policy, and still others discuss the present acquis in the sense of state of affairs within a given policy.

Constitutional acquis. It should be noted that the major part of Gialdino's article is devoted to an analysis of what he calls the fundamental or constitutional acquis and that this constitutional meaning of acquis probably is the one most contested. If I am not mistaken the support of this constitutional acquis has provided the very rationale of the entire article. Gialdino describes how two contending interpretations of the constitutional acquis compete. On the one hand the interpretation shared by Gialdino. His point of departure is Pescatore's classic distinction between an ordinary (accession) acquis and a constitutional acquis. The latter acquis clearly belongs to the legal sphere. It is

"made up of the fundamental principles concerning the structure of the legal order and the case law on the essential requirements of the Community, constitutes an untouchable hard core, that is, an absolute substantial restriction implicitly imposed on any revision. This acquis would be therefore bound to prevail even over primary rules, including the rule governing the revision itself" (1995:1108).

Gialdino finds support for this constitutional acquis in the ECJ's Opinion concerning the Agreement on the European Economic Area. He admits that the Opinion's section on the constitutional order of the Community is "particularly laconic and rather cryptic", furthermore that it has been "the subject of different interpretations", and finally that some writers - as well as the European Commission - have interpreted the ECJ's Opinion in a fashion which leads to a denial of the existence of an "untouchable" constitutional "hard core". Yet, Gialdino does not find such an interpretation persuasive. He points out that several writers (Bouloius, 1992; Barents, 1992; Huglo, 1992; De Cruz Vilaca and Picarra, 1993; and Gialdino, 1993) interpret differently. Furthermore, that the ECJ published its Opinion only after "The institutions and the Member States made their views known both in writing and orally at a hearing heldin camera" (1995:1110). Finally, that the interpretation according to which the ECJ "had adopted the theory elaborated by Carl Schmitt on a constitutional hard core (Verfassungskern) ... had already been accepted by a number of Constitutional Courts" (1995:1110). This would have been very powerful support for the constitutional acquis, had certain Protocols not been annexed to the TEU during the European Summit in Maastricht - ironically at the same time as the ECJ published its Opinion. After a lengthy analysis of the possible impact on the acquis of these protocols, Gialdino finishes his article on a note of perplexity and uncertainty about the future constitutional order of the European Union. I return to the issue in the section on possible threats to the acquis.

The purpose of this section was to make clear that there are several meanings of acquis in circulation. Debates on the acquis, its possible reform, and its future will clearly benefit from a more precise indication of various meanings. We see how discursive strategies have been employed, particularly a legal discourse that emphasize the untouchable constitutional status of the acquis. In contrast to the accession acquis (that concerns applicant states), the constitutional untouchable acquis concerns 
Member States, meaning that each one complements the other. Furthermore, the section demonstrates how the acquis is gradually being 'loaded with meaning', precisely what the genealogical method suggests.

\section{Is the acquis an endangered principle?}

Why, in the first place, raise the question? Do social actors not regularly question the principles guiding their thinking and action, and are principles therefore not always endangered? However, the reason to bring up the question is simply that in recent years a number of analysts have pointed out, if not warned us, that the acquis, as we know it, is under attack. What follows is consequently, in some sense, a threat analysis. The threats examined include i) "hijacking" (Curtin, 1993), ii) subsidiarity (Toth, 1994; Maher, 1995), iii) the intergovernmental conference 1996-97 (Gialdino, 1995), iv) the 5th enlargement (Preston, 1995), and v) the UK.

Hijacking. Curtin (1993) discusses whether the acquis has been hijacked. What does 'hijacked' mean in this context, and who is the 'hijacker'? The latter question is easy to answer. Curtin explicitly identifies the TEU negotiators as possible hijackers. The reason being the proliferate use of protocols annexed to the EC Treaty, not all protocols but particularly five that all tend to breach the acquis or could open for serious breaches in the future. First, we have Protocol No. 1 on Danish secondary residence and Protocol No. 17 on abortion in Ireland. Curtin argues that both protocols could represent the beginning of a dangerous trend towards acceptance of permanent derogations. Furthermore, Protocol No. 11 on the UK's opt-out of the third phase of the EMU, and Protocol No. 14 on Social Policy which includes an Agreement by 11 Member States, all willing to implement the Social Charter of 1989. The tricky thing is that the 11 declares that their Agreement "are subject to the acquis communautaire." Finally, there is Protocol No. 2 on Art. 119 EC, the so-called Barber Protocol, which many analysts consider to represent an illegal interference by the TEU negotiators in the competence of the ECJ.

Similarly, Gialdino (1995) finds that by using the 'annexing Protocols-technique', the Member States "have heavily impinged on the 'case law' acquis" (1995:1115), yet he focuses his analysis on the Barber Protocol. Gialdino shares Curtin's analysis of the problematic interpretation of Art. 119 by TEU negotiators - "a grave breach of the acquis" (1995:1118) - because interpretation of the Treaties is reserved the ECJ. However, by analyzing the ECJ's practice after the Maastricht Summit, Gialdino adds some interesting observations. He finds that the ECJ could have chosen between two alternatives: "considering the Protocol inapplicable", and "adopting a restrictive interpretation". Yet the Court adopted the interpretation of the TEU negotiators. So, not only was the Barber Protocol a grave breach of the acquis but the Court apparently also gave in to an illegal interpretation of the Treaty. He concludes that the TEU paradoxically "represent the alpha and omega of the acquis", a conclusion he shares with Judge Mancini who writes that "paradoxically, the Maastricht Treaty ratifies (Article B) and at the same time nullifies [the] evolution" (quoted from Gialdino, 1995: 1120, note 82). No wonder that Gialdino concludes his article on a somewhat pessimistic note:

"The next revision of the Treaty, fixed for 1996, represents a dangerous test for the acquis"..."The Court, which had contributed to the formation of the acquis by identifying the essential features of the Community legal order (direct effect, primacy) has been extremely weak when called upon to preserve and defend it; it gave up playing its typical function of constitutional guarantor and abandoned its role of 'guardian of the legal certainty'" (1995:1121). 
Gialdino published his article in 1995. What has happened since, apart from the intergovernmental conference 1996-97 and the signing of the Amsterdam Treaty? On the Barber Protocol, Stone Sweet and Caporaso (forthcoming) provide one possible answer. First, they note that the Court often functions as policy-maker, meaning that watertightness between 'political' and 'judicial' matters is far from being absolute. Next, they find that the protocol "did not reverse the Court's rulings". Rather, negotiators pointed our their preferred interpretation - something the Court was free to rule 'inapplicable'. Second, Stone Sweet and Caporaso conclude, with reference to a study by Whiteford on post-Maastricht rulings that "member states have not induced the Court to abandon its pre-protocol case law". In summary, it seems as if the "hijacking" threat to the acquis was merely conjunctural, and the string reactions by Curtin, Gialdino and others could well be part of the reason it remained a conjunctural threat. So much about hijacking by treaty negotiators and by means of protocols. We see how particularly Gialdino is a master of employing legal discursive power, in this case used against the political power of TEU negotiators. Stone Sweet and Caporaso's article suggests that 'offensive' political action around Maastricht has been 'rolled back'.

Subsidiarity. The introduction of a new principle into an existing order of principles is almost bound to produce turbulence and uncertainty about future relations between the principles. The introduction of the subsidiarity principle at the Edinburgh European Council in 1992 is no exception from this rule. Multiple Commission reports, Council declarations and an Interinstitutional Agreement have occurred in order to create a new balance. Did the subsidiarity principle have an impact on the acquis? Two rival interpretations can be identified. Before I present the interpretations, it is worth noticing that the document adopted in Edinburgh attempts to guard the acquis against possible undermining effects: "the application of the principle of subsidiarity shall respect the general provisions of the Maastricht Treaty including 'maintaining in full the acquis communautaire'" (quoted from Gialdino, 1995:1105-6). Both interpretive camps acknowledge this. Yet, Toth (1992) and Maher (1995) claim that there has been an impact. Maher repeats Toth's view that the new principle has been applied retroactively. She adds that "A revision of existing legislation which predates the principle inevitably counters the stated absence of effect on the acquis communautaire, and merely obfuscates the legal meaning and consequences of the principle" (1995:245). Maher concludes that a review "intended to promote simplification and consolidation is welcome, but the laudable objective has been hijacked by the inappropriate retroactive application of the subsidiarity principle to a pre-existing body of law. Change will come about, but at the expense of the acquis communautaire and as a result of the continuing failure of the EC institutions to face up to fundamental and irresponsible concerns about democratic accountability" (1995:251).

In contrast, Gialdino does not find that the subsidiarity principle has had an impact on the acquis. It "does not represent a retroactive application.... but rather it is a classic example of amendment of legislation, the development of which is necessarily influenced by historical factors" (1995:1106). He adds that the review carried out by the Commission has been "concerned with detailed and specific techniques" (ibid.). Once again we have rival interpretations. Only a thorough analysis of practice during the years 1992-1998 can settle which side has the better argument.(15)

The acquis, the IGC 1996-97, and the Amsterdam Treaty. The Amsterdam process includes the so-called Reflection Group, i.e. a group of personal representatives for national governments which had the delicate task of preparing the formal IGC.(16) The two Reflection Group reports are masterly written mixtures of balanced views, nuances, and explicitly stated priorities. It is a very interesting case of a disciplining discursive power exercise that has marginalized several potential items or imply removed them from the IGC's agenda. Among the explicitly stated priorities the group refers approvingly to the acquis provisions in the TEU, and state that the acquis should be maintained and 
further developed. Furthermore, the Group "rejects any formula which could lead to an à la carte Europe".(17) Finally, on the issue of enlargement and temporary derogations, the group maintains that "a 'critical mass' of 'acquis' essential for accession has to be preserved in spite of any flexible arrangement". In other words, the "mass" of temporary derogations should not be allowed to dilute the acquis into some meaningless "überbleibsel". In these examples, the Group's opinion is spelled out in clear language.

However, the Group also employs a balanced "both-and" approach. Thus, both flexibility and acquis: "flexible solutions will have to be found, fully respecting the single institutional framework and the "acquis communautaire"; both adjustment and maintenance of the acquis: "Maintenance of the 'acquis communautaire' should not, however, prevent the necessary adjustments from being made in order to respond to new situations. Neither, as we shall see below, should it prevent flexible formulae from being found on a case-by-case basis and where necessary to enable new stages of integration to be entered upon at different paces, without the objectives of a common project being jeopardized". Balancing became a task for IGC negotiators.

Third, the Group presented its views on selected issues. According to some members of the group there is "a risk of spill-over from the second "pillar" to the first, which reduces the efficiency of the Union and which could weaken the "acquis". Some are equally concerned by the opposite effect". According to the Group, the Union "must (also) be based on common principles which must be reaffirmed. They inspire the common core which characterizes the Community as an entity based on the rule of law, and in particular involve ... maintenance and development of the 'acquis communautaire' as a whole, as provided for by Article B of the Treaty". The group also points out that, "the degrees of flexibility admissible are different both under each of the three 'pillars' and also in the case of the present Member States and those acceding on next enlargement". Finally, the Group had clear priorities concerning the pillar structure of the Treaty, "Whereas derogations must not be allowed in the Community 'pillar' if they jeopardize the internal market and create discriminatory conditions for competitiveness, CFSP and some Justice and Home Affairs issues enable a greater degree of flexibility." The Reflection Group thus produced prudently phrased judgements on the likely or desirable future role of the acquis.

While it is difficult to analyze deliberations concerning the acquis during the formal IGC 1996-97, it is easy to trace the fate of the acquis in the output of the IGC, i.e., in the Amsterdam Treaty. The acquis is mentioned slightly more often in the new Treaty provisions than in the Maastricht TEU. It is significant that the TEU provisions are copied more or less (Article 2, indent 4; Article 3). The acquis should thus henceforth be maintained in full and developed. However, Article 43 is new and states that enhanced cooperation should not have an impact on the acquis: "Member States which intend to establish closer cooperation between them may make use of the institutions, procedures and mechanisms laid down by the Treaties provided that the cooperation ... does not affect the acquis communautaire and the measures adopted under the other provisions of the Treaties" - an echo of the advise given by the Reflection Group. Finally, the acquis is mentioned in provisions concerning the so-called Schengen provisions but in this context the term acquis is used for achievements within a specific policy-area. In summary: as things turned out, the IGC does not seem to have constituted a serious threat to the acquis. Despite much talk about flexibility, the acquis was if not strengthened then at least consolidated.

The 5th enlargement. Why should the 5th enlargement be a threat to the acquis? Arguments vary but focus on features like increasing economic diversity within the Union, an acknowledgement of the fact that enlargement makes revision of the acquis compulsory if decision-makers want to avoid 
skyrocketing of Common Agricultural Policy (CAP) and structural reform budgets, and the political attitude that it is somehow "unfair" to demand acceptance of the acquis 'in full and without conditions' from Central and East European states. Preston concludes his analysis saying that "Focus on the acquis is likely to remain a cornerstone, though in this case it begs more difficult questions about the revision of the acquis before the formal enlargement process commences....Clearly, transitional arrangements and technical adjustments would be utilized, though as has been noted there are limits as how far these can be stretched before they start to undermine the foundations of the acquis" (1995: 462). Reflections on the acquis are widespread in the European Commission's Communication Agenda 2000 (particularly Part Two: The Challenge of Enlargement). It is a very powerful document which distinguishes between "Euro-compatible" and "Euro-incompatible" applicants, informs about the political, economic, legal and administrative "software" that applicants have to "install" in their "state-machinery" in order to become compatible or improve their existing record. The Commission notes that its task "was unprecedented because the Copenhagen criteria are broad in political and economic terms and go beyond the acquis communautaire (for example, assessing administrative and judicial capacity". The Commission's assessment is dynamic in the sense that it is more than a retrospective analysis, and more than a status quo report. It also assesses likely future "medium term" developments in the Union, and notes that the acquis is evolving rapidly in such fields as environment, the Single Market and the information society. In passing, The Commission notes that, "The Amsterdam Treaty has enshrined in Article F a constitutional principle that 'The Union is founded on the principles of liberty, democracy, respect for human rights and fundamental freedoms and the rule of law'". Though the Commission acknowledges that the adoption of the acquis "is a difficult challenge" it nevertheless emphasizes that "As in previous enlargements, the European Council has ruled out any idea of a partial adoption of the acquis". The Commission therefore goes on to assess the implications of adopting the acquis in various fields, ranging from the Single Market to fields like "agriculture, environment, energy, transport and social policy". The taking on board the acquis is a huge task, and support to adaptation to the acquis has become a key feature of the EU's pre-accession strategy. The possible threat to the acquis stemming from the 5th enlargement does not seem very frightening as a partial adoption of the acquis has been ruled out. What remains a "threat" is the revision of the acquis within certain sectors prompted by enlargement. In other words, enlargement disturbs some of the balances created by the well known interests-create-policies policies-create-interests dialectics.

The United Kingdom. The United Kingdom is the only state among the Member States of the European Union that has called the acquis into question. From the mid-1990s and onwards, British Conservatives attacked the acquis fairly consistently. The attitude found expression in conservative newspapers like the Daily Telegraph and in speeches by the, at the time, British Prime Minister, John Major. Thus The Daily Telegraph published an editorial 'Alice in Santerland' which makes fun of some aspects of European Union policy-making: "to understand the stress that oysters suffer [from transportation], we must refer [readers] to a key text of the acquis communautaire, as the ECs body of law is known" (30 January 1996). Less than two months later, The Daily Telegraph published a second editorial on the acquis, 'Thanks, but no thanks', in which familiar Euro-speak jargon is mentioned with a pronounced disgust: "must promote the 'strengthening of economic and social cohesion', they must 'maintain in full the acquis communautaire' and so on." The editorial goes on: "This wearisomely familiar "onwards-and-upwards" European rhetoric... "the policy-making tendencies of the European Court, or dismantling the very doctrine of the acquis communautaire" (10 March, 1996). In the Summer of 1996 John Major tried the best he could to influence the agenda of the newly launched IGC. Headline: "Maastricht Social Chapter is Disastrous in Reality".. "The Variable Geometry Indispensable" ..."The Acquis Communautaire is not 'Etched in Stone"' (Agence Europe, 27 July 1996). British conservatives travelling in Central and Eastern Europe tried to lobby 
for a rejection of the Social Chapter: "You [Czechs] have been told that it is part of the acquis communautaire and that you have no choice" he said. "In our view that is wrong" (Reuter Newswire, 14 October 1996). These and other efforts did not have much impact on the outcome of the IGC, and in the meantime the Conservative Party has lost the 1997 national election to the Labour Party. What remains of this threat seems to be a time and party-specific negative attitude towards the acquis, and even this negative attitude should not be exaggerated too much. The Conservative Party is a stout supporter of the Single Market (SEM), of the acquis that regulates the Single Market, and of the ECJ in the role as the guardian of the SEM.

\section{Conclusion}

The analysis confirms the expectation of there not being one but many origins of the acquis, implying that searches for the "essence" or "deep truth" are futile, meaning in term that the acquis was in fact "fabricated in a piece-meal fashion". Whereas it was not possible to trace the very first mentioning of the term acquis communautaire it was possible to trace the accession acquis principle back to the early 1960s, to the first negotiations on enlargement between "The Six" and the United Kingdom. By means of several additions and transformations the acquis has acquired its present meaning. However, even today the acquis is a contested principle, in part because not all actors accept for instance its constitutional qualities. In general, I find that the continuity or change dilemma is best solved by simply refusing its narrow-minded logic. It is simply misleading to pose the question in terms of either-or. The well-known term, "classic fashion", suggests that we deal with timeless fashion that apparently never changes. In reality, however, every period has its version of "classic fashion" which, nevertheless, is characterized as "timeless". Someone wearing a piece of so-called timeless fashion from the 1930s and claiming it to be a piece of "modern" classic would not be trustworthy simply because we know a piece of modern classic when we see it. In my view, the same almost applies to the acquis. It is claimed to be non-changeable, a "classic" tool in the repertoire of European constructors, and somewhat it is such a tool. Yet, it also changes and has been changing ever since the term was coined to describe an important principle. For some time it was a political principle but later on it also became a legal and constitutional principle.

The second conclusion is that there is not one but several different meanings of acquis. Particularly Gialdino points out the different meanings of acquis and, within the category of accession acquis, between aspects and sorts of acquis. However, one should remember that such subtleties are unlikely to make it into the news bulletins that I scanned in the first section of the paper, meaning that the acquis in a broad public understanding will be that of "one acquis", rock-hard and unchangeable. To some degree, European politics will most likely be informed by precisely this narrow meaning of acquis for which reason clashes on the acquis between European law and politics will probably occur just as much in the future as in the past.

The third conclusion concerns the threat scenario. Yet, on the whole, the five listed threats to the acquis do not seem to have been serious threats, meaning that despite all worries, the acquis does not seem to be an endangered principle. While the principle was under attack by Maastricht TEU negotiators, it seems to have been a very short-term violation of European law (with, admittedly, long-term effects on the ECJ). In other words, we have seen an example of European politics 'overruling' European law and, as such, a violation of European law, something that lawyers and law experts naturally despise. Concerning the second threat, it still remains to be seen whether subsidiarity has had a lasting impact on the acquis. Different interpretations were presented and it was left to empirical analysis to provide an answer to the question. The third threat, the Amsterdam treaty reform exercise, was not the serious challenge to the acquis it was supposed to be. The result of the exercise, 
the Amsterdam Treaty, contains a number of provisions that can be interpreted as contradicting each other. Also the fifth threat, enlargement, does not at all seem to be a serious threat to the acquis. Again, European policies and regulations will for sure be changed due to enlargement but not in a way that violates the acquis principle.

Thus, despite some "ruptures", the analysis demonstrates that the acquis throughout almost 40 years has been predominantly characterized by reproduction, mutation and expansion. Different actors in and outside the Euro-polity have contributed to the genealogy of the acquis, indeed their shared understandings of the acquis have made the acquis what it is.

\section{References}

Arpio Santacruz, Marta (1991) Member States of the European Communities. Spain. Spanish adaptation to Community law: 1986-1988, European Law Review, 16(2):149-160.

Blumann, Claude; Denis, Dominique; Olive, Philippe (1991) Harmonisation du droit agraire en Europe: l'acquis, les besoins, les limites (I), Revue de droit rural, (190): 49-66.

Caporaso, James (1996) The European Union and Forms of State: Westphalian, Regulatory or Post-Modern, Journal of Common Market Studies, 34(1):29-53.

Christiansen, Thomas and Jørgensen, Knud Erik (1999) The Amsterdam Process. A Structurationist Perspective on EU Treaty Reform. European Integration online Papers (EIoP) 3 (1); http://eiop.or.at/eiop/texte/1999-001a.htm.

Cooper, Robert (1996) The Post-Modern State and the World Order, London: Demos.

Curtin, Deirdre (1993) The constitutional structure of the Union: A Europe of bits and pieces, Common Market Law Review, 30(1): 17-69.

Daviddi, Renzo; Ilzkovitz, Fabienne (1997) The Eastern enlargement of the European Union: Major challenges for macro-economic policies and institutions of Central and East European countries, European Economic Review, 41(3-5): 671-680.

Egger, Alexander (1996a) L'acquis communautaire et ses effets sur le droit autrichien (Iier partie), Revue du Marché Commun et de l'Union Européenne, (398): pp. 380.

Egger, Alexander (1996b) L'acquis communautaire et ses effets sur le droit autrichien (IIème partie), Revue du Marché Commun et de l'Union Européenne, (402): 648-655.

European Commission opinion on Austria's request for membership to the European Community (1991) Europe Documents, English edition, (1730): 1-3.

Fearon, J.D. (1991) Counterfactuals and Hyothesis Testing in Political Science, World Politics 43:169-95.

Flyvbjerg, Bent (1998) Rationality and Power: Democracy in Practice, Chicago: Chicago University Press.

Foucault, Michel (1971/1984) 'Nietzsche, Genealogy, History', in Paul Rabinow (ed.), The Foucault Reader, New York: Pantheon. 
Fraselle, Nadine (1994) La protection du consommateur et son intégration dans la politique communautaire de l'alimentation: orientations, acquis, évaluation, European Food Law Review, EFLR, 5(1): 1-33.

Garrone, Pierre (1993) Les droits du citoyen européen: l'acquis communautaire et l'apport du traité de Maastricht, Schweizerische Zeitschrift für internationales und europäisches Recht, 3: 251-271.

Gialdino, Carlo Curti (1995) Some reflections on the acquis communautaire, Common Market Law Review, 32(5): 1089-1121.

Goebel, Roger J. (1995) The European Union grows: the constitutional impact of the accession of Austria, Finland and Sweden, Fordham International Law Journal, 18(4): 1092-1190.

Hess, Hans-Joachim; Raaflaub, Patrick (1992) Die Auswirkungen des Acquis Communautaire auf das Recht des EWR, Europäische Zeitschrift für Wirtschaftsrecht, 3(12-24): 379-387.

Hulle, K.; Regoort, C.; Ruffing, L. (et al.) (1990) L'avenir de l'harmonisation comptable dans les Communautés européennes. Conférence des 17 et 18 janvier 1990 à Bruxelles, Document, (Objectif 1992) Office des publications officielles des CE. Luxembourg, (1990) 108 p. Ann.

Haas, Ernest B. (1953) The Balance of Power: Prescription, Concept or Propaganda?, World Politics, 5: 442-77.

Kratochwil, Friedrich (1989) Rules, norms, and decisions. On the conditions of practical and lehal reasoning in international relations and domestic affairs, Cambridge: Cambridge University Press.

Lenaerts, Koen (1994) Education in European Community law after "Maastricht". Common Market Law Review, 31(1): 7-41.

Loheac, F. (1988) A l'Horizon 1992, quelle libre prestation des services pour l'assurance? Revue du Marché Commun, (317): 271-273.

Maher, Imelda (1995) Legislative Review by the EC Commission: Revion without Radicalism, in Jo Shaw and Gillian More (eds.), New Legal Dynamics of European Union, Oxford: Clarendon Press.

Mahon, Michael (1992) Foucault's Nietzschean Genealogy. Truth, Power, and the Subject, Albany: State University of New York Press.

Nietzsche, Friedrich (1887/1969) On the Genealogy of Morals - Ecce Homo (Edited, with Commentary by Walter Kaufmann), New York: Vintage Books.

Pescatore, Pierre (1981) Aspects judiciaires de l'"acquis communautaire", Revue trimestrielle de droit européen, 21:617-651.

Preston, Christopher (1995) Obstacles to EU Enlargment: The Classical Community Method and the Prospects for a Wider Europe, Journal of Common Market Studies, 33(3): 451-463.

Price, Richard (1995) A genealogy of the chemical weapons taboo, International Organization, 49: 73-103.

Rabinow, Paul (ed.) (1984) The Foucault Reader, New York: Pantheon. 
Raelison Rajaobelina, Thierry (1994) La suppression des frontières techniques dans l'Union européenne, Notes Bleues de Bercy, Ministère de l'économie, des finances et du budget, (31): 6 p.

Rouam, Claude (1992) L'Espace Economique Européen: un horizon nouveau pour la politique de concurrence?, Revue du Marché Commun et de l'Union Européenne, (354): 53-57.

Scandamis, N.G.G. 1983. L'Europe, notre seule chance (Dossier), L'europeen, (215-216): 3-86.

Schmitter, Philippe C. (1996) Imagining the Future of the Euro-Polity with the Help of new Concepts. In Gary Marks, Fritz W. Scharpf, Philippe C. Schmitter and Wolfgang Streeck, Governnace in the European Union, London: Sage.

Smith, Steve (1995) The Self-Images of a Discipline. A Genealogy of International Relations Theory, in Ken Booth and Steve Smith (eds.), International Relations Theory Today, Cambridge: CUP.

Stone Sweet, Alec and Caporaso, James A. (forthcoming) The Court of Justice and European Integration, Revue Française de Science Politique.

Sussman, Michael, David Webb, Rebecca Peters et al. (1991) European Economic Area, International Financial Law Review, 10(12): 24-29.

Sørensen, Georg (1997) An analysis of contemporary statehood: consequences for conflict and cooperation, Review of International Studies, 23(3):253-269.

Wallace, Helen and William Wallace (eds.) (1996) Policy-Making in the European Union, Oxford: Oxford University Press.

Weiler, Joseph H.H. (1991) The Transformation of Europe, Yale Law Journal, 100: 2403-2483.

Weiler, Joseph H.H. (1997) The Reformation of European Constitutionalism, Journal of Common Market Studies, 35: 97-131.

Wendt, Alexander (1995) Constructing International Politics, International Security, 20:71-81.

Wiener, Antje (1997) European Citizenship Practice. Building Institutions of a Non-State, Boulder, CO.: Westview Press.

\section{Endnotes}

(*) For helpful comments and criticisms I am grateful to Hanne Marlene Dahl, Rodney Bruce Hall, Lykke Friis, and Tonny Brems Knudsen. Furthermore, I am thankful to Michael Nentwich and two anonymous referees for suggesting improvements. For research assistance, I am grateful to Kenneth Glarbo Andersen; to our librarian at the Department of Political Science, Karen Prehn; and to the staff at the European Commission's Central Library in Brussels.

(1) Eastern Europe and the EU. Laying down the law, The Economist, 10 December 1994.

(2) 'European Union Enlargement', http://www.diplomatie.fr/frmonde/euro/eu26.gb.html.

(3) My search through news bulletins covers the years 1995-1998 and includes data as covered by the Dialog databases. 
(4) Italics has been added to all quotations (KEJ).

(5) Most but not all data in my search contribute to the pattern I describe. I will come back to the few exceptions in sections below.

(6) Glossary. The reform of the European Union in 150 definitions, http://europa.eu.int/en/agenda/igc-home/en/g4000x.htm. Somewhat surprisingly the Vocabulaire du Droit Primaire Communautaire (Luxembourg: Office des publications officielles des Communautés européennne, 1985) does not have an entry for acquis communautaire.

(7) My analysis would most likely have benefitted from a better acquaintance with the conceptual history tradition. In general, I see the genealogical method as belonging to the repertoire of social constructivism, see the collection of working papers, The Aarhus-Norsminde Papers: Constructivism in International Relations and European Studies, Aarhus: Department of Political Science. See also 'The Social Construction of Europe', a Special Issue of Journal of European Public Policy (forthcoming September 1999).

(8) Other readings of Foucault have different purposes. Thus Mahon informs his readers that he regards Foucault's method as the "problematic which emerged for him in the course of his historical researches" (1992:1). Mahon adds that his philosophical project concerns the "three genealogical axes - truth, power, the subject", ibid.

(9) Ernest B. Haas, 'The Balance of Power: Prescription, Concept or Propaganda?, World Politics, V: 442-477 (1953); 'The Balance of Power as a Guide to Policy-Making, Journal of Politics, XV: 370-398 (1953); The Uniting of Europe (London: Stevens \& Sons, 1958); Beyond the Nation-State: Functionalism and International Organization (Stanford: Stanford University Press, 1964); 'The Joy and Anguish of Pre-Theorizing', International Organization, 24(4): 607-646 (1970); The Obsolescence of Regional Integration Theory (Berkeley: Centre for International Studies, 1975).

(10) I quote Price who quote Alexander Nehemas, who paraphrases Nietzsche. Also in scholarly work we can find many examples of "documents that have been scratched over and recopied many times" (Foucault, 1971: 26). It is for this reason it makes sense to analyze scholarly traditions and disciplines by employment of the genealogical method, see Smith (1995).

(11) For an overview of different official translations of the term, see Gialdino (1995:1089, note 1) or use the "translator's best friend on the web" - EURODICAUTON (http://www2.echo.lu/edic/).

(12) Curti Gialdino points out that a reference to the case law would have been inappropriate and legally incorrect, "Inappropriate, because it would have had the effect of 'freezing' the case law; legally incorrect, because it would have resulted in a difference of regime between the original and present Member States on the one hand and the applicant Member States on the other" (1995:1098). He adds that it is beyond doubt that the case law is included in the acquis.

(13) Note that Curti Gialdino traces this aspect back to the Declaration on European Identity, adopted in Copenhagen by the Heads of State and Government in December 1973, i.e. the Mediterranean enlargement was only an instance to confirm a key aspect of European identity.

(14) Guide to the Approximation of European Union Environmental Legislation. Annex 2: The Environmental Acquis, http://europa.eu.int/en/comm/dg11/guide/annex2.htm.

(15) Data for a thorough analysis includes at least Commission reports, from the Commission report to the European Council on the Adaptation of Community Legislation to the Subsidiarity Principle 
(24 November 1993), Better law-making, Bull. 11-1995, point 1.9.2 and onwards, Council declarations, the Interinstitutional Agreement.

(16) On the Amsterdam process, see Christiansen and Jørgensen (1999); Progress report from the Chairman of the Reflection Group on the Intergovernmental Conference (1 September 1995); "A Strategy for Europe" Final report from the Chairman of the Reflection Group on the Intergovernmental Conference, 5 December 1995.

(17) The Group's use of the term à la carte Europe is interesting. According to Stubb, the term does not contradict the acquis, something which the term variable geometry does, see Stubb, 1996. 


\section{Figure 1}

\section{Different Meanings of Acquis}

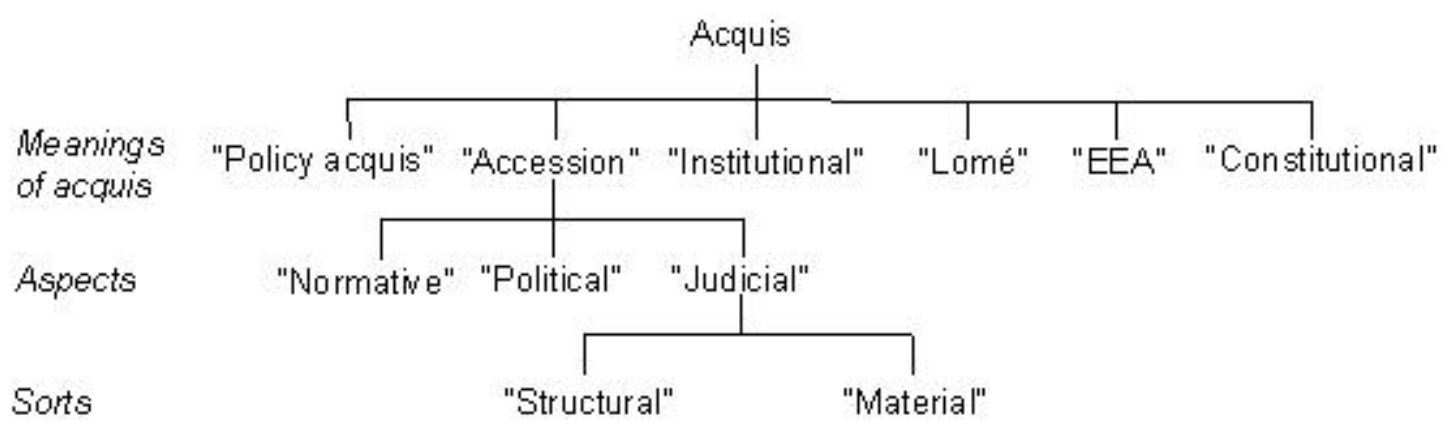

Source: Primarily based on Giald ino, 1995.

(C)1999 by Jorgensen

formated and tagged by MN, 23.4.1999 